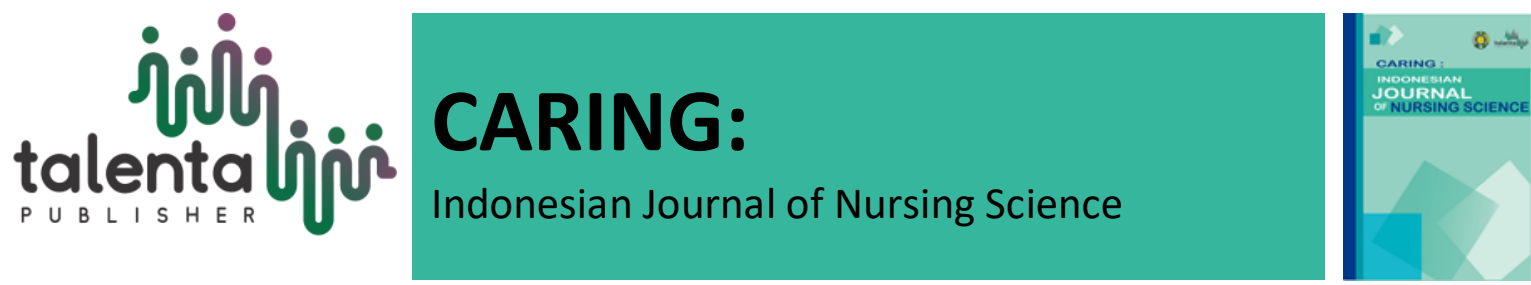

\title{
Factors Related to Community Knowledge of Rabies Management in Sintang, West Kalimantan
}

\author{
Siska Evi Martina ${ }^{1}$, Blasius ${ }^{2}$ \\ ${ }^{I}$ Nursing Science Program, Faculty of Pharmacy and Health Sciences, University of Sari Mutiara \\ ${ }^{2}$ Nursing students of Sint Carolus STIK
}

\begin{abstract}
Rabies is an acute infectious disease of central nervous system in the which is the effect of a zoonotic viruses that spread through direct contact to the wound or mucosa by infected animal saliva or paw. Rabies virus has been transmitted to human through a bite animal's rabies transmitters like dogs, car, and ape. Indonesia is a Country with a high prevalence of rabies. The low level of knowledge and lack of source of informations still leads the rabies prevention Become a serious problem. Purpose of this research is to knowing factors that influence society, the level of knowledge about management rabies in the village Sekubang, Sintang, Westlespondent. This research using quantitative descriptive correlation with cross sectional method approaches. There are 146 patriarch Sekubang respondent in the village that has been complied inclusion criteria. The research result shows that $63.7 \% 1$ espondent age 20-40, 49.3\% respondents only studied until elementary school, $86.3 \%$ got the information from healthcare workers, $91.1 \%$ has a risk environment, and $89 \%$ have a good knowledge. Kendall's tau-c and Chi-square test correlation statistically have a relation between age $(p=0.114)$, education $(p=$ $0.000)$, environment $(p=0.000)$, information from healthcare workers and the level of knowledge about rabies management.Therefore this research shows the source of information from healthcare workers is very important to Increase knowledge of rabies management.
\end{abstract}

Keyword: Rabies, Knowledge, Management

Received 04 October 2019 | Revised 29 December 2019 | Accepted 29 December 2019

\section{Introduction}

Rabies has attracted attention in the public health sector today. Rabies is an acute infectious disease of the central nervous system as a result of zoonotic viruses spread by direct contact with a wound or mucous saliva of an infected animal or scratches. Rabies virus is transmitted to humans through the bite of rabies animals such as dogs, cats and monkeys, the disease is when it shows clinical symptoms always ends with death (Moh RI, 2016).

\footnotetext{
*Corresponding author at: Jl. Prof.Maas No. 03 Kampus USU, Medan, Indonesia.

E-mail address: siskaevi21@gmail.com
} 
According to the Word Health Organization (WHO) states that around 55,000 people a year die from rabies, 95\% of that amount coming from Asia and Africa. Most of the approximately 30$60 \%$ of victims are children under the age of 15 years (WHO, 2010).

Indonesia in 2015 , the spread of rabies there is 25 provinces with a high enough bite cases. In 2014 and 2015 found 80.403 cases bite of an infectious rabies animal (GHPR). GHPR cases mostly occurred on the island of Bali with a number of 42.630 cases, followed by East Nusa Tenggara as many as 7.386 cases. As for deaths from rabies are 118 cases, occur most widely in North Sulawesi and Bali as many as 28 cases of 15 cases (Ministry of Health, RI 2016).

West Kalimantan is a new area infected with rabies. This province previous as the free area form rabies and animal bite rabies cases, but in the end of the year cases are found to be increasing. Based on data in 2014/2015 the number of dog bite cases of rabies reached 702 people and the death cases amounted to 18 people.

While in the sub sepauk it self occurred 79 cases of bites from 2016 to 2017 and the Sekubang village as the highest bite cases (26 cases). The village it self Sekubang ranging numbered 200300 families (KK) with a population of 1800 inhabitants and approximately 100 families who raise dogs to be left in the wild uninhibited. And community treatment of dogs is very close, the dog is considered as a guard house and a friend when they go hunting or to the fields. Dogs in the area was never given much of a vaccine for health workers so that the limited information regarding the prevention of rabies. (Sepauk the District Health Office, 2017).

In the prevention of rabies, knowledge and attitudes will affect the management action. In a study revealed that people who have a good knowledge against rabies will do early prevention and it will reduce the incidence of rabies (Ni Kadek Septiani, 2014).

Exposure to effective medical resource about rabies and its management is very important relation in increasing knowledge and positive attitude to prevent the spread of disease. This situation can be explained due to health behaviors are influenced by media exposure as one of the factors of management, where the presence of exposure to information media will make one change that will eventually be followed by a change in behavior and increase knowledge in this case related to the prevention of rabies ( Jane, Kandou, Ratag, 2015). Therefore, this study aims to identify factors that affect the level of public knowledge aboutmanagement rabies in the village Sekubang

\section{Methods}

This research is descriptive with cross sectional approach. Samples are heads of household in the village Sekubang, which can read and write, and who have or do not have a pet dog, with a sample of 146 heads of household. Sampling using purposive sampling method. The study was conducted in February and March 2018. 


\section{Results}

Sekubang village is a area in the district Sepauk, Sintang West Kalimantan, with a population of approximately 1800 inhabitants with a total of 230 heads of household head of the family. The village has an area of 7100 ha, and in the eastern part bordering the village long Landau, South bordering Wake Village, and directly adjacent to the western part of the village of Naga Pemubuh Sekadau. Village Community economy generally edged Sekubang search as farmers are tapping rubber and gold mining, and there are some civil servants who work as teachers in schools. Village Community Sekubang $90 \%$ embraced the Catholic religion, and originate from the Dayak tribe Seberuang. This study was conducted at the health center Sekubang because of the data sub-district Rabies incidence of dog bites in the Village is quite high.

Table 1. Frequency Distribution Characteristics of Respondents $(\mathrm{N}=146)$

\begin{tabular}{lcc}
\hline \multicolumn{1}{c}{ Characteristics of Respondents } & Frequency & \% \\
\hline Age & 8 & 5.5 \\
17-25 years & 28 & 19.2 \\
26-35 years & 57 & 39.0 \\
36-45 years & 48 & 32.0 \\
46-55 years & 5 & 3.4 \\
$\quad$ 56-65 years & 72 & 49.3 \\
Education & 62 & 42.5 \\
Elementary - Junior High School & 12 & 8.2 \\
High School & & \\
Diploma / Degree & 133 & 91.1 \\
Environment & 13 & 8.9 \\
Risk & & \\
Not at Risk & 126 & 86.3 \\
Provision of Information & 20 & 13.7 \\
Ever & & \\
Never &
\end{tabular}

According to the table 1 above, it is known that the presentation of $5.5 \%$ of respondents aged 17-25 years of age by 8 respondents, $19.2 \%$ at 26-35 years of age were 28 respondents, $39.0 \%$ by the age of $36-45$ years as many 57 respondents, $32.0 \%$ by the age of $46-55$ years as many as 48 respondents, $3.4 \%$ at $56-65$ years of age by 5 respondents. Meanwhile, related to the education level, $49.3 \%$ of respondents are primary and junior by 72 respondents, $42.5 \%$ were in high school, and 8.2\% are Diploma-Bachelor. The Result of shows most respondents had primary education or lower level. Of environmental. Based on table $91.1 \%$ of the respondents live in environments at risk of rabies.

According to the observation of the researcher at the time showed that the surrounding environment is still a lot of stray dogs that roam, and obtained information that the respondents who keep dogs never gave vaccinate his dog. So the results of this study, respondents were very high risk environment as much as 133 respondents (91.1\%). Besides providing 
information from health officials about rabies covers $86.3 \%$ of respondents had never received information from health officials about rabies, but there are still 126 respondents (13.7\%) never get information from health officials.

Table 2. Frequency Distribution of Respondents Knowledge Level Rabies Treatment $(\mathrm{N}=$ 146)

\begin{tabular}{lcc}
\hline \multicolumn{1}{c}{ Knowledge } & Frequency & $\%$ \\
\hline Well & 130 & 89 \\
Enough & 14 & 9.6 \\
Less & 2 & 1.4 \\
\hline Totally & 146 & 100 \\
\hline
\end{tabular}

Based on the overview of the level of knowledge about the management of rabies (Table 2), it is known that $89 \%$ of respondents already have a good knowledge, $9.6 \%$ sufficient knowledge, and and $1.4 \%$ lacking knowledge.

Table 3. Relationship between age with levels of knowledge about management Rabies $(\mathrm{N}=$ 146)

\begin{tabular}{|c|c|c|c|c|c|}
\hline \multirow[t]{2}{*}{ Age head of the family } & \multicolumn{3}{|c|}{ Knowledge } & \multirow[t]{2}{*}{ Totally } & \multirow{2}{*}{$\begin{array}{c}P- \\
\text { value }\end{array}$} \\
\hline & Well & Enough & Less & & \\
\hline $17-25$ years & 7 & 1 & 0 & 8 & \\
\hline $26-35$ years & 27 & 1 & 0 & 28 & 0.114 \\
\hline $36-45$ years & $\begin{array}{l}52 \\
30\end{array}$ & $\begin{array}{l}4 \\
8\end{array}$ & 1 & $\begin{array}{l}57 \\
48\end{array}$ & \\
\hline $46-55$ years & 5 & 0 & 0 & 5 & \\
\hline $56-65$ years & & & & & \\
\hline Totally & 130 & 14 & 2 & 146 & \\
\hline
\end{tabular}

From the above table known that the age of the heads of families as much as 8 respondents 1725 years, 7 of them with good knowledge, and one knowledge enough. Age 26-35 years were 28 respondents, 27 of them with good knowledge, and one knowledge enough, ages 36-45 years as many as 57 respondents, 52 of them with good knowledge, 4 respondents' knowledge of sufficient, and one respondent with less knowledge, ages 46- 55 of 48 respondents, 39 of them with good knowledge, 8 respondents knowledge enough, and one respondent knowledge lacking, aged 56-65 years by 5 respondents, 5 of them with good knowledge. From the test results Kendall's tau-c between the ages characteristic variable head of the family with knowledge about the prevention of rabies showed P-value of 0.114 . Because the value of $p>$ 0.05 
Table 4. The relationship between education level with levels of knowledge about management Rabies $(\mathrm{N}=146)$

\begin{tabular}{|c|c|c|c|c|c|}
\hline \multirow[t]{2}{*}{ Education KK } & \multicolumn{3}{|c|}{$\begin{array}{c}\text { Knowledg } \\
\mathrm{e}\end{array}$} & \multirow[t]{2}{*}{ Totally } & \multirow[t]{2}{*}{$\begin{array}{c}P- \\
\text { value }\end{array}$} \\
\hline & Well & Enough & Less & & \\
\hline Elementary-Junior High School & 58 & 12 & 2 & 72 & \\
\hline High School & 60 & 2 & 0 & 62 & 0,003 \\
\hline Diploma / Degree & 12 & 0 & 0 & 12 & \\
\hline Totally & 130 & 14 & 2 & 146 & \\
\hline
\end{tabular}

Education primary and junior head of the family as much as 72 respondents, 58 of which knowledge is good, 12 knowledge enough, and 2 with less knowledge, a high school education were 62 respondents, 60 of them are knowledgeable good, and 2 with enough knowledge. Education Diploma-Degree as many as 12 respondents and all of them with good knowledge. From the test results Kendall'tau-c between education characteristic variable head of the family with knowledge about the prevention of rabies showed P-value of 0.000 . Because the value of p> 0.05 , so it can be concluded that there is a significant relationship between education families with knowledge about the management of rabies in the village Sekubang, Sintang, West Kalimantan.

Table 5. The relationship between the environment and levels of knowledge about management Rabies ( $=146)$

\begin{tabular}{|c|c|c|c|c|c|}
\hline \multirow[t]{2}{*}{ Environment } & \multicolumn{3}{|c|}{ Knowledge } & \multirow[t]{2}{*}{ Total } & \multirow{2}{*}{$\begin{array}{l}P \text { - } \\
\text { value }\end{array}$} \\
\hline & Well & Enough & Less & & \\
\hline risky & 130 & 2 & 1 & 133 & \\
\hline not at risk & 0 & 12 & 1 & 13 & \\
\hline Total & 130 & 14 & 2 & 146 & \\
\hline
\end{tabular}

Table 5 shows that the head of the family environment at risk as many as 133 respondents, 130 of which knowledge is good, two with enough knowledge. And one less knowledge. The surroundings were not at risk as much as 13 respondents, 12 of them are knowledgeable good, and 2 with enough knowledge. From the results of Chi-Square test between the variables of environmental characteristic head of the family with knowledge of the management of rabies showed P-value of 0.000. Because the value of $p>0.05$, so it can be concluded that there is a significant relationship between the environment head of the family with knowledge of the management of rabies in the village Sekubang, Sintang, West Kalimantan. 
Table 6. Relationship between Giving Information to levels of knowledge about management Rabies $(\mathrm{N}=146)$

\begin{tabular}{lcccrcc}
\hline Provision of Information & & Knowledge & Totally & $\begin{array}{l}P \text { - } \\
\text { value }\end{array}$ \\
& Well & Enough & Less & & \\
\hline Yes (Never) Never & 118 & 7 & 1 & 126 & \\
& 12 & 7 & 1 & 20 & 0,000 \\
\hline Totally & 130 & 14 & 2 & 146 & \\
\hline
\end{tabular}

Table 6 shows the provision of information from health professionals to the head of the family. Which ever of 126 respondents, 118 of them good knowledge, 7 with sufficient knowledge. And one less knowledge. That was never as much as 20 respondents, 12 of which had good knowledge, 7 with sufficient knowledge, and one with less knowledge. From the results of ChiSquare test between variable characteristics of the provision of information from health professionals with knowledge about the prevention of rabies showed P-value of 0.000 . Because the value of $p>0.05$, so it can be concluded that there is a significant relationship between the provision of information from health professionals with knowledge about the management of rabies in the village Sekubang, Sintang, West Kalimantan.

\section{Discussion}

In this study, the factors affecting the level of knowledge about management rabies is the level of education, the environment and the provision of information. While age is not a factor that affect a person's knowledge about the management of rabies in the village Sekubang. These results are not in line with research conducted by Julien Patricya, et al, (2015) says there is a relationship between the age of the dog owner and the prevention of rabies in Puskesmas Tobelo. A similar study conducted by Malahayati, (2010) says that the age variable effect on the dog owner's participation in the prevention of rabies. From the observations of researchers obtained enthusiastic families in receiving incoming information about rabies so that both young or old age despite knowledge of rabies remains good. This is supported (Wicaksana, 2012) the man will use motoric ability, logical reasoning and creative thinking and supported by the physical abilities that are still able to compete, which in this case is to gain knowledge about the prevention of rabies. Thus, according to researchers sparing no relationship between age with knowledge about the prevention of rabies in the village of West Kalimantan Sintang Sekubang. The level of education among the factors that affect, according as the opinion Notoadmodjo (2012), said that the factors affecting the level of knowledge one of which is the level of education. It is associated with a good understanding and knowledge head of family because according to the theory Notoatmodjo (2012), said that knowledge is a factor facilitate behavioral change, in this case of rabies prevention measures. Furthermore, knowledge is also very important in the formation of a person's actions in this case is the act of the respondent for the 
prevention of rabies. The level of education also determine whether or not a person is easy to absorb and understand the knowledge acquired, in general, the higher one's education the better the knowledge. Similarly, in this case the respondents expected the higher education the higher the knowledge about the prevention of rabies. Environmental factors also affect the level of knowledge. This is in line with research conducted by Julien patricya, (2016) says that there is a significant relationship between the purpose of a dog with Tabelo rabies at community health center prevention efforts. It is also in line with research conducted by the Sri Utami, (2012). Saying that there is a relationship between the way a dog-keeping with the implementation of the vaccination program. A significant association between the environment and knowledge about the prevention of rabies. Because according to the results showed that there are many stray dogs that roam around the house respondent, and obtained the respondent was never vaccinating pet dogs. This is supported by the theory that the environment is a condition that is around humans and can affect the development and behavior of individuals or groups.

A very important factor and should be improved is the provision of information about the management of rabies for the community. These results are consistent with research conducted by Glendy Salomon et al (2015) found a significant correlation between the availability of health care information with the village Motoling rabies precautions because the $\mathrm{P}$-value $=$ 0.011. Results of another study also conducted by Tahulending (2014) in the Village Aertembaga Bitung say that there is a significant relationship between health services with rabies prevention measures. Based on observation showed that previously had been given information from health professionals, so that the knowledge head of family very well with the number of 118 respondents.

\section{Conclusion}

From the results obtained the factor affect the level of public knowledge about the management of rabies in the village Sekubang, Sintang West Kalimantan are education, the environment and resources of health care workers. These results can be rekomended for the health department, department of animal husbandry and related agencies to follow up on rabies treatment program.

\section{REFERENCES}

[1] Budiman, A. (2013). Knowledge and attitudes in health research. Jakarta: Salemba Medika.

[2] Batan, IW, \& Suatha, IK (2016). Factors that Encourage Genesis Rabies in dogs on the Villages in Bali (Factors Encouraging The Incidence Of Rabies In Dogs In Villages In Bali). Veterinary Journal, 17 (2), 274-279.

[3] https://ojs.unud.ac.id/index.php/jvet/article/view/22130

[4] West Kalimantan Provincial Health Office. (2014). Health Profile of West Kalimantan province in 2014. Taken back from the $\mathrm{MOH}$. 
[5] West Kalimantan Provincial Health Office. (2015). West Kalimantan Provincial Health Profile 2015 health profile.

[6] Digafe, RT, Kifelew, LG, \& Mechesso, AF (2015). Knowledge, attitudes and practices towards rabies: questionnaire survey in rural household heads of Gondar Zuria District, Ethiopia. BMC research notes, 8 (1), 400.

[7] https://bmcresnotes.biomedcentral.com/articles/10.1186/s13104-015-1357-8

[8] DVM. Hiswani, M. (2003). prevention and eradication of rabies. medical journals USU Faculty of Public Health.

[9] Gunawan, CA, \& Harijanto, PN (2007). Medicine. Jakarta: Department of Medicine.

[10] Hoetama, E., Tanri, NP, Gianni, LF, Kusuma, KB, Gunardi, HD, and Suryadi, EF (2017). Knowledge, Attitudes, and Behavior against Rabies in Manggarai regency, East Nusa Tenggara, Indonesia, 2014. eJournal Medicine, 177-82.

[11] http://journal.ui.ac.id/index.php/eJKI/article/viewArticle/7111

[12] Ignatavicius, Donna; Workman, Linda. (2016). Medical-Surgical Nursing Collaborative Patient- Contered care. Canada: Elseiver.

[13] Lesnussa, JP, Mulyadi, N., \& Malara, R. (2016). Relationship Characteristics Own Dog With Rabies Prevention Efforts In Puskesmas Tobelo North Halmahera. JOURNAL OF NURSING, 4 (1).

[14] https://ejournal.unsrat.ac.id/index.php/jkp/article/view/11898

[15] Mandal, BK, Wilkins, EG, Dunbar, EM, \& Mayon-White, RT (2008). 6. edition Infectious Diseases Jakarta: publisher.

[16] Mubarak \& Wahit, I. d. (2009). Community Nursing Science: Concepts and Applications. Jakarta: Salemba Medika.

[17] Matibag, GC, Kamigaki, T., Kumarasiri, PV, Wijewardana, TG, Kalupahana, AW, Dissanayake, DA, ... and Tamashiro, H. (2007). Knowledge, attitudes, and practices survey of rabies in a community in Sri Lanka. Environmental health and preventive medicine, 12 (2), 84-89.

[18] https://link.springer.com/article/10.1007/BF02898154

[19] Notoadmojo, S. (2012). Health Promotion and Health Behavior. Jakarta: Rineka Reserved.

[20] Notoatmodjo, S. (2007). Health Promotion and Behavioral Sciences. Jakarta: Rineka Reserved.

[21] Notoatmodjo, S. (2010). Research Methodology Health and Health Behavior. Jakarta: Rineka Reserved.

[22] Perry, P. (2013), Fundamentals of Nursing. Issue 7. Jakarta: Salemba Medika

[23] Polit, DF, \& Beck, CT (2014). Nursing Research. Philadelphia: Wolters Kluwer.

[24] Rahayu, A. (2008) .Rabies.Surabaya: FKWijayaKusuma. http://mahasiswa.dinus.ac.id/docs/skripsi/jurnal/19771.pdf

[25] Retno Bintari, A. (2016). Rabies Knowledge Level Differences In Kader Posyandu Yang Di Provide Health Education Teaching Methods And Leaflets In Sintang District, West Kalimantan (Doctoral dissertation, University of Muhammadiyah Surakarta).

[26] http://eprints.ums.ac.id/42234/

[27] RI, KK (2014). Indonesia's health profile 2014 Jakarta: Ministry of Health RI. 
[28] RI, KK (2016). Never No More Deaths Rabies. data center and information RI health ministry.

[29] Sabono, JJ, Jootje, M, L, Umboh, and Kepel, B, J (2016) factors relating to preventive measures of rabies in a dog owner in the Village Shoulder Malalayang District of Manado City in 2016. http://medkesfkm.unsrat.ac.id/index.php/faktor-faktor-yangberhubungan-dengan-tindakan-pencegahan-rabies-pada-pemilik-anjing-di-kelurahanbahu-kecamatan-malalayang-kota- Manado-year-2016-2 /

[30] Salomon, GA, Kaunang, WP, \& Kawatu, PA (2017). The factors associated with rabies in the village precautions Motoling Motoling District of South Minahasa District ikmas 2015, 2 (5).

[31] https://ejournalhealth.com/index.php/ikmas/article/view/539

[32] Sancheti, PV, and Mangulikar, SK (2017). An interventional study to assess knowledge regarding rabies in secondary school students. International Journal of Community Medicine And Public Health, 3 (1), 180-183.

[33] http://www.ijcmph.com/index.php/ijcmph/article/view/669

[34] Sutarga, M., \& Suariyani, P. Dog Maintenance System as One Animal rabies in Patients Rabies in Bali in 2011. Archive of Community Health, 1 (1), 50-54.

[35] https://ojs.unud.ac.id/index.php/ach/article/view/8725/6468,

[36] Susilo, WH (2013). Principles - Principles of Biostatistics and SPSS applications. Jakarta: IN MEDIA.

[37] Sutrisno, D. (2015). Knowledge, Attitudes, and Behavior Faculty of Human Ecology, Bogor Agricultural University against Rabies.

[38] http://repository.ipb.ac.id/handle/123456789/77708

[39] Tahulending, JM, Kandou, GD, \& Ratag, B. (2015). Factors related to the preventive measures of rabies in the Village Makawidey Aertembaga District of Bitung. JIKMU, $5(2)$.

[40] https://ejournal.unsrat.ac.id/index.php/jikmu/article/view/7183

[41] Wattimena, JC (2010). Some risk factors for incidence of rabies in dogs in Ambon. Journal of Public Health, 6 (1).

[42] https://journal.unnes.ac.id/nju/index.php/kemas/article/view/1748

[43] Henry, \& Goddess, M. (2011). Theory and Measurement of Attitudes and Human Behavior. Yogyakarta: Multi Medika. 